\title{
EFEKTIVITAS PENGGUNAAN MEDIA KINEMASTER TERHADAP \\ KEMAMPUAN MENULIS TEKS PROSEDUR SISWA KELAS VII \\ SMP SWASTA MUHAMMADIYAH O5 MEDAN
}

TAHUN PEMBELAJARAN 2019/2020

\author{
${ }^{1}$ Eka Indriani, ${ }^{2}$ Tangson R. Pangaribuan \\ Prodi Pendidikan Bahasa dan Sastra Indonesia, Univers itas Negeri Medan \\ Email: ${ }^{1}$ ekaindrianihsb@gmail.com, ${ }^{2}$ tangson.rp@gmail.com)
}

\begin{abstract}
Abstrak
Penelitian ini bertujuan untuk mengetahui Efektivitas Penggunaan Media Kinemaster Terhadap Kemampuan Menulis Teks Prosedur Siswa Kelas VIISMP Swasta Muhammadiyah 05 Medan Tahun Pembelajaran 2019/2020. Populasi dalam penelitian ini adalah seluruh siswa kelas VII yang terdiri dari 4 kelas yang berjumlah 128 siswa. Sampel penelitian ini adalah kelas VII-A yang berjumlah 32 siswa dan kelas VII-B yang berjumlah 32 siswa. Penelitian ini menggunakan metode penelitian eksperimen. Desain penelitian yang digunakan pa da penelitian ini adalah two group post test design. Berdasarkan pengolahan data, diperoleh hasil be lajar siswa dalam membuat teks prosedur pada kelas kontrol dengan nilai rata-rata sebesar 70, sedangkante ks prosedur pada kelas eksperimen adalah 82.Dari uji data yang dilakukan pada kelas kontrol dan kelas eksperimen, diketahui bahwa kedua data tersebut berdistribusi normal. Dari data pada kelas kontrol diperoleh $\mathrm{L}_{\text {hitung }}<\mathrm{L}_{\text {tabel }}(0.15625<0.158)$, dan pada kelas eksperimen diperoleh $\mathrm{L}_{\text {hitung }}<\mathrm{L}_{\text {tabel }}(0.115428013<0.158)$. Dari uji homogenitas diperoleh bahwa sampel penelitian ini berasal dari kelompok yang homogen yaitu Fhitung < Ftabel $(0.9<1.82)$. Selanjutnya $t_{0}$ dikonsultasikan dengan $t_{\text {tabel }}$ pada taraf signifikan $5 \%$ dengan $\mathrm{dk}=70$, maka diperoleh 1.57. Oleh karena $\mathrm{t}_{0}$ yang diperoleh lebih besar dari tabel yaitu 150>1.57, maka $\mathrm{H}_{\mathrm{a}}$ diterima. Hal in $\mathrm{i}$ membuktikan bahwa media Kinemaster efektif terhadap kemampuan menulis teks prosedur siswa kelas VIISMP Swasta Muhammadiyah 05 Medan tahun pembelajaran 2019/2020.
\end{abstract}

Kata Kunci : media kinemaster, kemampuan menulis teks prosedur

\section{A. PENDAHULUAN}

Pembelajaran merupakan proses kegiatan belajar yang di dalamnya melibatkan peran serta guru dan siswa. Selain keterlibatan guru, pembelajaran juga berkaitan erat dengan kurikulum dan perkembangan IPTEK. Pembelajaran 
dalam Kurikulum 2013 menuntut siswa untuk lebih aktif serta guru yang harus selalu kreatif dalam merancang media pembelajaran agar proses pembelajaran berjalan sesuai yang direncanakan.Pembelajaran Bahasa Indonesia dalam Kurikulum 2013 menyuguhkan pembelajaran yang berbasis teks. Materi pembelajaran teks prosedur dalam pelajaran bahasa Indonesia sebagai salah satu bagian dari kompetensi dasar dalam Kurikulum 2013. Hal ini dipertegas dengan Kompetensi Dasar bahasa Indonesia SMP kelas VII yaitu: 3.5, 4.5, dan 3.6, 4.6 dengan memperhatikan struktur, unsur kebahasaan dan isi secara lisan dan tulis dan akan lebih difokuskan pada keterampilan tentang cara memainkan atau membuat sesuatu dari media kinemaster secara tulis.

Berdasarkan pengamatan penulis, terdapat masalah dalam proses pembelajaran menulis teks prosedur pada siswa kelas VII SMP Swasta Muhammadiyah 05 Medan. Guru sudah membentuk siswa dalam kelompok, tetapi dalam kelompok be lajar hanya beberapa orang saja yang mengerjakan tugas yang diberikan oleh guru, sedangkan yang lain tidak terlibat. Selain itu, guru tidak memerhatikan siswa saat belajar di dalam kelompok. Hal ini terlihat dari hasil menulis teks prosedur siswa yang belum mencapai KKM. Mata pelajaran Bahasa Indones ia memiliki nilai KKM 75, sedangkan siswa hanya memperoleh nilai 65.

Melihat kondisi demikian perlu dicarikan solusi alternatif dalam pembelajaran menulis dan daya tarik dalam pembelajran, supaya segala permasalahan serta kendala yang terdapat dalam siswa maupun guru dapat teratasi maka diperlukan media pembelajaran yang memudahkan siswa untuk menulis teks prosedur yaitu media kinemaster.

Peneliti memilih media pembelajaran berbasis kinemaster karena sudah ada hasil penelitian yang menunjukkan berhasilnya penerapan media pembelajaran ini. Adapun penelitian tersebut yaitu : Pembelajaran Teks Report dengan Proyek "Cerdig" Berbasis Kinemaster yang ditulis oleh Laily Amin Fajariyah pada tahun 2018 menyatakan hampir semua siswa menyatakan setuju apabila pembelajaran Bahasa Inggris dengan proyek cerdig berbasis Kinemaster itu menyenangkan. Hanya ada 1 (satu) siswa yang tidak yakin atas jawabannya. Karena merasa senang dan termotivasi, partisipasi siswa juga meningkat 
dibuktikan dengan beberapa siswa merasa terlibat aktif. Dengan meningkatnya partisipasi siswa dalam pe mbelajaran dan perasaan senang di kelas, proyek "cerdig" berbas is Kinemaster ini diyakini siswa mampu meningkatkan pemahaman mereka tentang teks report yang dipelajari. Siswa setuju dengan peningkatan pemahaman mereka terhadap informasi yang a da dalam teks report yang mereka pilih. Hasil wawancara dengan tiga siswa yang telah dipilih secara acak mendukung hasil angket ini. Ketiga anak tersebut ketiga ditanya mengenai teks yang mereka buat cerita digitalnya bisa memberikan informasi rinci terkait teks mereka. Bahkan salah satu siswa masih mengingat nama latin dari binatang yang ada dalam cerita digital mereka. Pendapat mereka sesuai dengan hasil ulangan harian KD 11.3 di mana siswa yang tuntas meningkat dengan penggunaan proyek "cerdig" berbasis Kinemaster. Nilai rata-rata hasil belajar mereka juga meningkat. Selain meningkatkan pemahaman siswa terhadap teks report yang mereka pelajari, proyek ini juga diyakini oleh banyak siswa mampu meningkatkan keterampilan berbicara mereka khususnya dalam teks report, terutama dalam keterampilan bercerita atau berbicara secara monologue, khususnya aspek pelafalan dan kelancaran. Asil ini mendukung pernyataan Robyler \& Doering (2013: 25) bahwa teknologi mampu melibatkan siswa dalam karya produksi. Dalam hal ini, produksi bahasa Inggris berupa teks report dalam bentuk cerita digital.

Selain meningkatkan pemahaman terhadap teks dan keterampilan berbicara siswa terutama dalam teks report, banyak siswa meyakini kalau proyek ini meningkatkan keterampilan mereka da lam teknologi informasi dan komunikasi (TIK) antara lain dalam mengunduh gambar, melakukan digital storytelling dengan Kinemaster, dan mengakses youtube dan mengunggah video di youtube.

Penelitian ini, menuntut siswa berperan aktif mengikuti pembelajaran yang dilakukan oleh guru. Dengan arahan yang diberikan oleh guru, yakni menuliskan teks prosedur ke dalam media kinemaster berdasarkan struktur teks prosedur yang berlaku didalam buku Bahasa Indonesia kelas VII SMP, membuat teks prosedur menjadi lebih menarik lagi dengan adanya media tersebut 
Berdasarkan latar belakang tersebut, penulis tertarik melakukan penelitian dengan judul "Efektivitas Penggunaan Media Kinemaster Terhadap Kemampuan Menulis Teks Prosedur Siswa Kelas VII SMP Swasta Muhammadiyah 05 Medan Tahun Pembelajaran 2019/2020".

\section{B. KAJIAN TEORI}

Keterampilan menulis merupakan salah satu keterampilan yang harus dimiliki siswa. Kegiatan menulis merupakan kegiatan yang paling utama dalam proses pengumpulan data dan tugas yang diberikan oleh guru di sekolah untuk semua bidang mata pelajaran yang ada. Tarigan (2008: 3) menyatakan bahwa menulis merupakan suatu keterampilan berbahasa yang digunakan untuk berkomunikasi secara tidak langsung atau tidak secara tatap muka dan menulis merupakan kegiatan yang produktif dan ekspresif.

Kosasih dkk (2017: 81) menyatakan bahwa teks prosedur merupakan tentang cara melakukan sesuatu dan cara membuat (cara memainkan alat music/ tarian daerah, cara membuat kuliner khas daerah, dll) dari berbagai sumber yang dibaca dan didengar dalam kehidupan sehari-hari. Kita menggunakan teks prosedur untuk memberikan petunjuk agar seseorang dapat melakukan suatu pekerjaan secara tepat. Agar kegiatan dapat secara tepat dan akurat serta memperoleh hasil maksimal sesuai dengan prinsip dan struktu yang ada pada teori dari teks prosedur.

Kinimaster merupakan aplikasi untuk mengedit video dengan tampilan komputer dengan tampilan ponsel. Aplikasi ini mendukung banyak lapisan video, audio, gambar, teks, dan efek. Video kinimaster dapat juga langsung dibagikan pada platform media sosial.

\section{METODE PENELITIAN}

Metode yang digunakan dalam penelitian ini dalah metode eksperimen dengan desain Two group Post-test Design. Metode Two Group Post-test Design merupakan eksperimen yang dilaksanakan pada dua kelompok yaitu kelompok 
kontrol dan kelompok eksperimen. Penelitian dilakukan dengan pemberian perlakuan dan tahap akhir peneliti memberi post test. Dari post test kelas kontrol dan ke las eksperimen dapat dilihat dari efektivitas penggunaaan media kinemaster terhadap kemampuan menulis teks prosedur siswa kelas VII SMP Swasta Muhammadiyah 05 Medan tahun pembelajaran 2019/2020.

\section{HASIL DAN PEMBAHASAN PENELITIAN}

Perolehan data kemampuan menulis teks prosedur menggunakan media kinemaster dapat dideskripsikan sebagai berikut.

\section{Tabel 1}

\section{Identifikasi Kecenderungan Hasil Tes Kelas Ekspe rimen}

\begin{tabular}{cccc}
\hline Rentang & Frekuensi F. & Relatif & Kategori \\
\hline $90-100$ & 14 & $43,75 \%$ & Sangat Baik \\
$81-90$ & 4 & $12,5 \%$ & Baik \\
$61-80$ & 12 & $37,5 \%$ & Cukup \\
$41-60$ & 2 & $6,25 \%$ & Kurang \\
$20-40$ & 0 & $0 \%$ & Sangat Kurang \\
\hline
\end{tabular}

Dari tabel di atas, diketahui bahwa kemampuan menulis teks prosedur dengan menggunakan media Kinemaster termasuk dalam kategori sangat baik sebanyak 14 orang (43,75\%), kategori baik 4 orang (12,5\%), kategori cukup 12 orang $(37,5 \%)$, kategori kurang 2 orang $(6,25 \%)$ dan sangat kurang tidak ada.

Perolehan data kemampuan siswa dalam menulis teks prosedur menggunakan model pembelajaran discovery learning dapat dideskripsikan sebagai berikut.

Tabel 2

Identifikasi Kecenderungan Hasil Tes Kelas Kontrol

\begin{tabular}{lccc}
\hline Rentang & Frekuensi & F. Relatif & Kategori \\
\hline $90-100$ & 0 & $0 \%$ & Sangat Baik \\
$81-90$ & 3 & $9,37 \%$ & Baik \\
$61-80$ & 20 & $62,5 \%$ & Cukup \\
$41-60$ & 9 & $28,12 \%$ & Kurang \\
$20-40$ & 0 & $0 \%$ & Sangat Kurang \\
\hline \multicolumn{4}{c}{} \\
\hline
\end{tabular}


Dari tabel di atas, diketahui bahwa kemampuan menulis teks prosedur dengan menggunakan model discovery learning termasuk dalam kategori sangat baik tidak ada, kategori baik 3 orang (9,37\%), kategori cukup 20 orang (62,5\%), kategori kurang 9 orang $(28,12 \%)$ dan kategori sangat kurang tidak ada.

Berdasarkan hasil penelitian yang dilakukan di kelas kelas VII SMP Muhammadiyah 05 Medan, dapat disimpulkan bahwa nilai yang diperoleh siswa setelah menggunakan media Kinemaster yaitu nilai terendah 60 dan nilai tertinggi 95. Nilai rata-rata sebesar 82 dan standar deviasi 10,85. Adapun kategori penilaian ditinjau dari 5 aspek, yakni kategori sangat baik sebanyak 14 orang (43,75\%), kategori baik 4 orang (12,5\%), kategori cukup 12 orang (37,5\%), kategori kurang 2 orang $(6,25)$ dan kategori sangat kurangtidak ada. Dari pemerolehan nilai ratarata tersebut, dapat diketahui bahwa kemampuan siswa dalam menulis teks prosedur masuk pada kategori sangat baik.

Berdasarkan hasil penelitian yang dilakukan di kelas VII SMP Muhammadiyah 05 Medan, dapat disimpulkan bahwa nilai yang diperoleh siswa setelah menggunakan model pembelajaran Discovery Learning tanpa menggunakan media Kinemaster yaitu nilai terendah 50 dan nilai tertinggi 90. Nilai rata-rata sebesar 70 dan standar deviasi 10,45. Adapun kategori penilaian ditinjau dari 5 aspek yakni kategori sangat baik sebanyak 3 orang (9,37\%), kategori baik 6 orang (18,75\%), kategori cukup 14 orang (43,75\%), kategori kurang 9 orang $(28,12 \%)$ dan kategori sangat kurang tidak ada. Dari pemerolehan nilai rata-rata tersebut, dapat diketahui bahwa kemampuan siswa dalam menulis teks prosedur masuk pada kategori baik.

Pada penggunaan media Kinemaster hasil penilaian dari aspek isi, 10 siswa $(31,25 \%)$ memperoleh skor maksimal yakni 3 sedangkan pada penggunaan model pembelajaran Discovery Learning 3 siswa (9,37\%) memperoleh skor maksimal yakni 3.

Pada penggunaan media kinemaster hasil penilaian dari aspek kelengkapan struktur, 18 siswa $(56,25 \%)$ memperoleh skor maksimal yakni 3 sedangkan model Discoveri Learning 3 siswa (9,37\%) memperoleh skor maksimal 3. 
Pada penggunaan media kinemaster hasil penilaian dari aspek kaidah penulisan, 11 siswa $(34,37 \%)$ memperolehskor maksimal yakni 3 sedangkan pada pembelajaran model Discovery Learning $3(9,37 \%)$ siswa memperoleh skor maksimal 3.

Pada penggunaan media kinemaster hasil penilaian dari aspek kaidah kebahasaan, 9 siswa $(28,12 \%)$ memperoleh skor maksimal yakni 4 sedangkan pada pembelajaran model Discovery Learning 4 (12,5\%) siswa memperoleh skor maksimal 3.

Adapun keunggulan dari model pembelajaran Discovery Learning yaitu dari hasil penilian aspek ke lengkapan struktur, 12 siswa $(37,5 \%)$ sedangkan media kinemaster 10 siswa $(31,25 \%)$ dengan siswa memperoleh skor atau kategori penilaian baik yaitu 2. Dapat di simpulkan bahwa dalam aspek kelengkapan struktur model discovery learning lebih baik. Hal ini dikarenakan beberapa keunggulan dari model discovery learning menurut (Hanifa dan Suhana 2012: 79) yaitu, teknik ini mampu membantu siswa untuk menge mbangkan, me mperbanyak kesiapan, serta penguasaan keterampilan dalam proses kognitif siswa dan dapat membangkitkan motivasi dan gairah belajar para siswa untuk belajar lebih giat lagi. Sehingga mampu membuat para siswa lebih kritis dan mendalami sesuatu yang ia pe lajari.

Dari penjelasan di atas dapat disimpulkan bahwa media kinemaster lebih efektif digunakan daripada menggunakan model pembelajaran Discovery Learning terhadap kemampuan menulis teks prosedur. Hal ini sesuai dengan hasil yang diharapkan, yaitu meningkatkan hasil belajar siswa dengan menggunakan media kinemaster dan juga KKM (Kriteria Ketuntasan Minimal )yang telah ditetapkan sekolah tersebut.

Peningkatan nilai tersebut terjadi karena siswa lebih termotivasi dalam belajar setelah diterapkannya Media kinemaster. Hal tersebut sejalan dengan Kinemaster adalah salah satu program penyuntingan video secara profesional yang bisa digunakan di smartphone (www.kinemaster.com, 2017). Fajariyah (2017: 154-7) menyampaikan langkah-langkah menggunakan Kinemaster untuk pembuatan cerita digital sebagai berikut: membuat proyek baru, memasukkan 
visuals/video dari media browser,memasukkan audio (recording atau file), memberikan efek dan menyunting timeline, menyimpan save video. Pada langkah terakhir menyimpan video (save video).

Dari penjelasan tersebut, membuat siswa lebih tertarik dalam pembelajaran karena menampilkan sebuah video yang lebih menarik perhatian mereka dan memfokuskan indra penglihatan mereka pada satu fokus penjelasan yang ada pada media yang di tampilkan.

Sehingga dengan menggunakan media ini, siswa tidak akan bosan, merasa senang, menarik perhatian siswa dan dapat mengembangkan wawasan mereka dalam hal pengetahuan. Hasil pengamatan tersebut menunjukkan bahwa suatu pembelajaran bermakna bagi siswa dan mampu menyentuh segenap aspek yang dimilikinya, maka tidaklah mustahil jika ada siswa yang mampu mencapai hasil pembelajaran yang jauh lebih baik dari apa yang dibayangkan oleh perancang pembe lajaran.

Selain itu, pembelajaran dengan menggunakan media kinemaster ini adalah pembelajaran yang memberikan kesempatan kepada anak untuk memanfaatkan inderanya sebanyak mungkin dalam kegiatan pembelajaran. Peserta didik tidak hanya duduk diam di tempat mendengarkan penjelasan dari guru, akan tetapi mereka diajak bergerak secara aktif dan kreatif sehingga mereka turut terlibat atau mengalami sendiri peristiwa pembelajaran dan menemukan sendiri inti yang dipelajari. Hal ini sesuai dengan teori konstruktivisme bahwa semua pengetahuan adalah hasil konstruksi dari kegiatan atau tindakan seseorang (Suprijono, 2010:31) dengan kata lain konsep yang ditemukan secara mandiri akanmembuat mahasiswa lebih paham dan mengingat materi lebih lama dibandingkan dengan sekedar menghafal konsep.

Meningkatnya kemampuan siswa dalam menulis teks prosedur dengan media Kinemaster di dukung dengan hasil penelitian dari Laily dkk (2018) dalam jurnal yang berjudul "Pembelajaran Teks Report Dengan Proyek "CERDIG" Berbasis Kinemaster". Hasil dari penelitian tersebut, menunjukkan adanya peningkatan hasil belajar siswa setelah menggunakan media Kinemaster. Perbedaan dari penelitian ini, terdapat pada tingkat kelas sampel penelitiannya. 
Penelitian yang dilakukan oleh Laily dkk menggunakan sampel kelas IX Sekolah Menengah Pertama (SMP) sedangkan sampel yang digunakan oleh peneliti adalah kelas VII Sekolah Menengah Pertama (SMP).

\section{E. KESIMPULAN}

Berdasarkan hasil analis is data yang diperoleh dari penelitian dapat disimpulkan, sebagai berikut.

1. Kemampuan siswa kelas VII SMP Swasta Muhammadiyah 05 Medan Tahun Pembelajaran 2019/2020 dalam menulis teks prosedur menggunakan model media Kinemaster termasuk dalam kategori sangat baik dengan nilai rata-rata 82.

2. Kemampuan siswa kelas VII SMP Swasta Muhammadiyah 05 Medan Tahun Pembelajaran 2019/2020 dalam menulis teks prosedur menggunakan model pembelajaran Discovery Learningt ermasuk dalam kategori cukup dengan nilai rata-rata 70 .

3. Pengujian hipotesis diperoleh $t_{\text {tabel }} 150>1,57$ hal ini membuktikan media Kinemaster efektif terhadap kemampuan menulis teks prosedur siswa VII SMP Swasta Muhammadiyah 05 Medan Tahun Pembelajaran 2019/2020.

\section{F. SARAN}

Sebagai tindak lanjut dari penelitian ini, maka perlu diungkapkan beberapa saran. Adapun saran yang dapat diberikan, sebagai berikut.

1. Bagi guru bidang studi bahasa Indonesia, kemampuan siswa dalam menulis teks prosedur perlu diperhatikan dan ditingkatkan lagi. Media Kinemaster ini dapat menjadi alternatif untuk meningkatkan kemampuan menulis teks prosedur siswa.

2. Selain menggunakan model pembelajaran, guru hendaknya menggunakan media pembelajaran yang lebih menarik dan bervariasi untuk menunjang 
penggunaan media pembelajaran agar siswa mampu memahami dan tertarik untuk belajar.

Disarankan agar penelitian selanjutnya tetap memperhatikan penggunaan media atau model pembelajaran yang digunakan di sekolah khususnya dalam pembe lajaran menulis teks prosedur.

\section{DAFTAR PUSTAKA}

Fajariyah, L.A.2018. Pembelajaran Teks Report Dengan Proyek "CERDIG" Berbasis Kinemaster. Jurnal Didaktika Pendidikan Dasar, Volume 2 Nomor 1 Tahun 2018, 182-192

Hanifiah, Nanang \& Suhana, Cucu. 2012. Konsep Strategi Pembelajaran. Bandung: PT. Reflika Aditama

Kosasih, E dkk. 2017. Bahasa Indonesia Kelas VII Edisi Revisi 2017. Balitbang: Kemendikbud

Suprijono, A. 2010. Cooperative Learning. Teori dan Aplikasi Paikem. Yogyakarta: Pustaka Belajar

Tarigan, Henry Guntur. 2008. Menulis Sebagai Suatu Keterampilan Berbahasa. Bandung: Angkasa 